\title{
Ekspresi Gen dan Laju Sintasan Udang Vaname (Litopenaeus vannamei) yang Tersuplementasi Dengan Alginat Secara Oral Untuk Resistensi Penyakit White Spot Syndrome Virus
}

\author{
Ervia Yudiati \\ Program Studi Ilmu Kelautan,Fakultas Perikanan dan Ilmu Kelautan,Universitas Diponegoro \\ Kampus Tembalang,Semarang 50275 Telp/Fax. 024-7474698 \\ Email:eyudiati@gmail.com
}

\begin{abstract}
Abstrak
Tingkat eskpresi gen Lectin/Toll dan laju sintasan ditentukan setelah udang vaname diberi pakan yang mengandung alginat dengan dosis berbeda dan diuji tantang dengan WSSV. Ekspresi gen dilakukan dengan qRT-PCR dan dihitung dengan metode komparatif menggunakan $\beta$-actin sebagai kontrol internal. Laju sintasan dihitung pada jam ke 96 setelah uji tantang. Ekspresi gen Lectin pada Udang mengalami upregulated setelah uji tantang, sedangkan ekspresi gen Toll mengalami down-regulated. Laju sintasan pada udang yang diberi suplementasi alginat $2,0 \mathrm{~g} \cdot \mathrm{kg}^{-1}$ dan $4,0 \mathrm{~g} \cdot \mathrm{kg}^{-1}$ lebih tinggi $(\mathrm{P}<0,05)$ apabila dibandingkan dengan tanpa suplementasi.
\end{abstract}

Kata kunci: ekspresi gen, laju sintasan, Litopenaeus vannamei, alginat

\begin{abstract}
The rate of Lectin/Toll gene expression and survival rate were determined after WSSV challenged. The shrimps were supplemented with alginate in different dose by oral administration. The gene expression was determined by comparative methods with $q R T-P C R$ and used $\beta$-actin as internal controle. The survival rate was counted at $96 \mathrm{~h}$ after WSSV challenged. The Lectin expression was up-regulated after challenged and the Toll gene was down-regulated. The survival rate of $2.0 \mathrm{~g} . \mathrm{kg}^{-1}$ dan $4.0 \mathrm{~g} . \mathrm{kg}^{-1}$ supplemented shrimps were higher $(P<0.05)$ when compared to the unsupplemented shrimp.
\end{abstract}

Keywords: gene expression, survival rate, Litopenaeus vannamei, alginate

\section{PENDAHULUAN}

Udang vaname (L. vannamei) dikenal secara luas merupakan species yang penting karena mempunyai nilai ekonomis yang tinggi, terutama di negara-negara berkembang termasuk Indonesia (Bai et al., 2014). Agar produksi udang dapat meningkat, para petambak melakukan intensifikasi tambaknya dengan memaksimalkan padat tebar pada lahan yang relatif sempit. Akibatnya, terjadi penurunan kondisi lingkungan dan stres yang memicu timbulnya penyakit, terutama yang disebabkan oleh WSSV (White Spot Syndrome Virus) (Musthaq et al., 2012). Diperkirakan, selama 15 tahun ini, produksi udang dunia mengalami kerugian sekitar 15 milyar \$ US (Flegel., 2012). Udang yang terkena serangan virus menjadi menurun imunitasnya (Yeh et al., 2009) sehingga hal yang mendesak dan perlu untuk dilakukan adalah dengan mencegah terjadinya penyakit dan meningkatkan resistensi udang terhadap serangan penyakit.
Immunostimulan adalah agen profilaksis yang ramah lingkungan. Secara umum, immunostimulan akan meningkatkan sistem immun non-spesifik udang dalam menghadapi serangan penyakit (Isnansetyo et al., 2014).

Sargassum sp. adalah salah satu species dari alga cokelat tropis yang mudah tumbuh dan sangat mudah untuk dipanen. Sargassum $s p$. merupakan sumber senyawa bioaktif baik metabolit primer atapun sekunder. Alginat adalah suatu komponen dinding sel dari rumput laut cokelat yang dikenal sebagai suatu substansi yang mempunyai aktivitas immunomodulator. Sodium alginat komersial dan ekstrak kasar dari Sargassum sp. (Yeh et al., 2009; Liu et al., 2006, Cheng at al., 2005) Gracilaria lemaniformes ( $\mathrm{Yu}$ et al., 2016) secara efektif dapat memodulasi sistem immun udang penaeid. Melalui penelitiannya, Isnansetyo et al. (2014) melaporkan bahwa alginat dari spesies lokal Indonesia Sargassum sp mampu meningkatkan

\footnotetext{
*) Corresponding author

http://ejournal.undip.ac.id/index.php/buloma

Diterima/Received : 28-07-2016

buloma.undip@gmail.com

Disetujui/Accepted : 25-08-2016
} 
parameter ketahanan nonspesifik ikan Lele (Clarias batrachus). Meskipun demikian, masih sedikit informasi yang tentang dosis efektif dari alginat, terutama dari species alga cokelat lokal yang mampu menanggulangi serangan WSSV, khususnya pada udang vaname (L. vannamei), sehingga penelitian ini perlu dilakukan.

\section{MATERI DAN METODE}

\section{Teknik Pembuatan Alginat dari Sargassum sp dan suplementasi pakan}

Sargassum sp. dikoleksi dari pantai Sundak, Gunung Kidul, Yogyakarta. Ekstraksi alginat dilakukan dengan menggunakan metode dari Jork et al, (2010). Ekstraksi dilakukan dengan penambahan $5 \% \quad \mathrm{Na}_{2} \mathrm{CO}_{3} / 50 \mathrm{mM}$ EDTA dan dilakukan dalam waktu semalam. Pelet yang dihasilkan disaring dan ditambahkan $0.13 \mathrm{M} \mathrm{KCl}$ dan dipresipitasi dengan ethanol $96 \%$ serta diaduk kuat hingga homogen. Sentrifugasi kemudian dilakukan pada kecepatan 3,500 rpm selama 5 menit. Alginat kemudian dikumpulkan dan dikeringkan dalam oven pada suhu $60^{\circ} \mathrm{C}$ selama semalam.

Alginat ditimbang sesuai perlakuan, kemudian dilarutkan dalam 2-3\% progol ${ }^{\circledR}$ (PT. INDOSCO, Surabaya), dan disemprotkan pada pakan komersial ( $C P$, Thailand) secara merata.

\section{Teknik persiapan inokulum WSSV}

Persiapan inokulum WSSV dibuat dengan memotong satu gram jaringan insang udang positif WSSC dan dilarutan dengan $9 \mathrm{ml}$ Phosphate Buffer Saline (PBS). Penghitungan jumlah copy virus dilakukan dengan real-time polymerase chain reaction (qRT-PCR) 7,500 Fast Real Time PCR (Applied Biosystem), menggunakan TaqMan probe. (PE Applied Biosystems, Foster City, CA, USA). Adapun konsentrasi WSSV adalah 2,0 x $10^{7}$ copi $\mathrm{ml}^{-1}$. Inokulum kemudian disimpan pada suhu $-80^{\circ} \mathrm{C}$. Sebelum digunakan dilakukan thawing, disentrifugasi pada $8000 \mathrm{rpm}$ selama 30 menit. Supernatannya diambil dan disaring dengan menggunakan filter steril $0,45 \mu \mathrm{m}$.

\section{Reinfeksi}

Reinfeksi dilakuan untuk meningkatkan stock virus WSSV dari stock virus koleksi BBPBAP, Jepara. Sebelumnya sejumlah 15 ekor udang ditempatkan dalam satu buah akuarium. Inokulum yang sudah siap kemudian diinjeksikan pada udang sebanyak $0,1 \mathrm{ml} / \mathrm{ekor}$. Pada jam ke 36, ditemukan udang yang telah mati, dan udangudang yang lain telah menampakkan gejala klinis karena infeksi $W S S V$ yang khas yaitu timbulnya warna kemerahan pada seluruh tubuh udang. Sisa udang kemudian dipanen dan disimpan dalam freezer $-80^{\circ} \mathrm{C}$. Konfirmasi terhadap keberadaan WSSV dilakukan dengan nested PCR.

\section{$U j i L D_{50}$}

Udang yang digunakan untuk uji $\mathrm{LD}_{50}$ didapatkan dari tambak pembesaran BBPBAP, Jepara, Indonesia. Isolasi DNA dilakukan dengan menggunakan lysis buffer. PCR teknik diaplikasikan untu mengindentifikasi dan memastikan bahwa udang tidak terinfeksi WSSV dengan menggunakan kit (GoTaq ${ }^{\circledR}$ DNA Polymerase, Promega) sesuai dengan prosedur dari pabrikan. Udang diperlihara dalam bak fiber $\left(1 \mathrm{~m}^{3}\right)$, dan diaklimatisasikan pada suhu ruang $\left(26-28^{\circ} \mathrm{C}\right)$ selama lima hari. Udang kemudian dipindahkan ke delapan buah bak plastik. Setiap perlakuan diset menjadi dua bak dan terdapat dua bak yang diperlakukan sebagai kontrol. Setiap bak diisi dengan 1201 air filter dan ditebar dengan 15 ekor udang dengan berat rata-rata 16.7-19.1 g. Perlakuan yang diterapkan adalah suatu serial pelarutan pada $0.01,0.001,0.0001$ and 0.00001 dari $2,0 \times 10^{7}$ copi $\mathrm{ml}^{-1}$. Larutan stok dibuat dengan menghomohenisasi satu gram udang terinfeksi WSSV dengan sembilan ml PBS steril yang disaring dengan $0,45 \mu \mathrm{m}$ kertas saring steril.

\section{Uji Coba Pakan}

Udang dipelihara dalam bak fiber dengan volume satu $\mathrm{m}^{3}$ dan diaklimatisasi pada suhu ruang $\left(26-28^{\circ} \mathrm{C}\right)$ selama dua minggu. Selama periode aklimatisasi, udang diberi pakan berupa pakan kontrol. Untuk memastikan bahwa udang tidak terinfeksi dengan WSSV, dilakukan pengujian dengan nested PCR (GoTaq ${ }^{\circledR}$ DNA Polymerase, Promega). Dua set percobaan diaplikasikan. Satu set digunakan untuk uji tantang dengan WSSV, satu set yang lain digunakan untuk penentuan laju sintasan dan pertumbuhan.

Udang dipindah ke dalam 1201 bak plastik dan ditebar dengan 12 ekor udang berukuran 15.417.4 g. Untuk laju sintasan, disiapkan 12 bak plastik yang ditebar dengan 20 ekor udang. Setiap bak diberi aerasi secara terus menerus. Kualitas air dijaga dengan penggantian air sebanyak $50 \%$ setiap harinya.

\section{Evaluasi terhadap ekspresi gen dan jumlah copi WSSV Ekspresi gen}

Ekstraksi total RNA didapatkan dari hemolim udang dengan Kit High Pure Viral- 
mRNA Extraction (Roche, Germany) dan dilaksanakan sesuai dengan prosedur dari pabrikan. Sintesa cDNA dari total RNA didapatkan dengan menggunakan Kit $A M V$ Reverse Transcriptase Kit (Roche, Germany) dan diatur pada suhu $42^{\circ} \mathrm{C}$ selama 30 menit, yang dilanjutkan dengan inaktivasi enzim transkriptase (Roche, Germany) pada suhu $42^{\circ} \mathrm{C}$ selama 30 menit. Ekspresi dari gen Lectin dan Toll dianalisa dengan menggunakan Sybr Green (Kapa SYBER FAST qpcr Master Mix) (Kapa biosystems) serta instrumen 7,500 Fast Real Time PCR (Apllied Biosystem). Adapun primer yang digunakan seperti yang terlihat pada Tabel 1. qPCR dikondisikan sbb: pre denaturasi $\left(94^{\circ} \mathrm{C}, 7\right.$ menit), denaturasi $\left(95^{\circ} \mathrm{C}, 30\right.$ detik, 45 siklus), annealing $\left(60^{\circ} \mathrm{C}, 30\right.$ detik, 45 siklus), extension $\left(68^{\circ} \mathrm{C}, 50\right.$ detik, 45 siklus) dan melting curve pada $95^{\circ} \mathrm{C}$ setelah 30 menit (Yudiati et al., 2016). Untuk menentukan tingkat ekspresi gen, data dianalisa dengan menggunakan metode komparatif (Livak \& Schmittgen, 2001) dan dinormalisasi menggunakan $\beta$-actin sebagai kontrol internal.

\section{Uji Tantang dan jumlah copi WSSV}

Pada hari ke 14 setelah pemeliharaan, udang yang berasal dari perlakuan kontrol (0); 2,0 dan 4,0 $\mathrm{g} \mathrm{kg}^{-1}$ ditantang dan diinjeksi dengan WSSV pada konsentrasi $1 \times 10^{5}$ copi udang ${ }^{-1}$. Pada jam ke 0, 12, 24 dan 36 pasca infeksi (hpi), hemolim dari dua ekor udang pada setiap perlakuan dikumpulkan, dicampur dan dilakukan ekstraksi. Ekstraksi DNA dilakukan dengan melakukan pooling hemolim dengan lysis buffer (GeneReach Biotechnology, Taipei, Taiwan) dengan teknik sesuai dengan instruksi pabrikan. Jumlah copi WSSV diukur dengan menggunakan TaqMan reagent (PE Applied Biosystems, Foster City, CA, USA). Untuk mendapatkan kurva standar, dilakukan serial pengenceran terhadap standar DNA dengan enam konsentrasi berbeda yaitu $12.500,1.250,125,12,5,1,25,0,125$ copi $\mathrm{ml}^{-1}$ yang sebanding dengan 100.000, 10.000, $1.000,100,10$ and $5 \mathrm{WSSV}$ copi $\mathrm{ml}^{-1}$. Untuk mendapatkan konsentrasi 12,500 copies $\mathrm{ml}^{-1}$ dilakukan dengan menambahkan $3 \mu \mathrm{l}$ standart stok DNA dan $27 \mu 1$ nuclease free water (NFW). Master mix disiapkan dengan mencampur 2xqPCR Master Mix $(2.5 \mu \mathrm{l}), 25 \mathrm{x}$ WSSV Primer probe Mix $(1 \mu \mathrm{l})$, NFW $(3.5 \mu \mathrm{l})$, sehingga volume totalnya adalah $17 \mu$ l. Master mix dengan volume $17 \mu \mathrm{l}$ itu kemudian dipipetkan ke dalam micro well, ditambahankan $8 \mu \mathrm{l}$ sampel DNA, kontrol tanpa template serta kontrol positif, sehinggan volume akhirnya adalah $25 \mu \mathrm{l}$. q-PCR dikondisikan sbb: $95^{\circ} \mathrm{C}, 10$ menit (DNA-activation Hot Start), $95^{\circ} \mathrm{C}, 5$ detik and $60^{\circ} \mathrm{C}, 45$ detik $(40$ siklus).

\section{Laju Sintasan}

Percobaan secara laboratoris terhadap laju sintasan dilakukan dengan menebar 20 ekor udang berukuran 3.1-4.0 g ke dalam 12 bak plastik. Setiap bak diisi dengan 1201 air laut filter. Rancangan yang digunakan adalah RAL dengan tiga kali ulangan. Adapun perlakuannya adalah dosis alginat $\left(0 ; 2,0\right.$ dan 4,0 $\left.\mathrm{g} \mathrm{kg}^{-1}\right)$. Pada hari ke 30 , udang pada semua perlakuan termasuk kontrol diinjeksi dengan WSSV pada konsentrasi $1 \times 10^{5}$ copi udang ${ }^{-1}$. Laju sintasan dihitung pada akhir jam ke 96 setelah uji tantang.

\section{Analisa data}

Data ekspresi gen dan jumlah copi WSSV diolah secara deskriptif. Data sintasan hidup diolah dengan menggunakan Anova satu arah dengan tingkat kepercayaan 0,05. Apabila terdapat beda nyata, maka untuk mengetahui beda nyata di dalam perlakuan, digunakan Uji Beda Nyata Terkecil (BNT). Data diolah dengan menggunakan DSAASTAT.XLS computer software.

\section{HASIL DAN PEMBAHASAN \\ Inokulum udang positif WSSV}

Konfirmasi terhadap keberadaan WSSV dapat dilihat dalam Gambar 1. Hasil pengujian terhadap sampel (S) menunjukkan adanya pita yang berpendar pada $1447 \mathrm{bp}$ dan $941 \mathrm{bp}$. Sehingga reinfeksi pada udang vaname berhasil dan WSSV yang diinfeksikan terkategori ganas.

Tabel 1. Primer yang digunakan dalam pengujian tingkat ekspresi gen

\begin{tabular}{cll}
\hline \multicolumn{1}{c}{ Gen } & \multicolumn{1}{c}{ Primer 5'-3' } & Referensi \\
\hline \multicolumn{1}{c}{ Lectin } & F: TTTGTAAACAACAGGCAGTTCCAC & Zhang et al, 2009 \\
& R: CTGTCTTTCATCAGAATGCTACCTC & \\
Toll & F: CATGCCTGCAGGACTGTTTA & Wang et al., 2012 \\
& R: GGCCTGAGGGTAAGGTCTTC & \\
B-actin (Internal & F:CCTCCACCATGAAGATCAAGATCAT & \\
kontrol) & R:CACTTCCTGTGAACAA TTGATGGTC & Sun et al., 2007 \\
\hline
\end{tabular}


$L D_{50}$

Pada jam ke 48, jumlah udang yang mati pada tiap konsentrasi dihitung dan hasil perhitungannya dapat dilihat pada Tabel 2. Lima puluh persen mortalitas udang didapatkan pada pengenceran sebesar $0,05\left(\mathrm{LD}_{50}=0,005\right)$ sehingga konsentrasi WSSV yang digunakan untuk uji tantang adalah $1 \times 10^{5}$ copi udang $^{-1}$ (EPA, 1996).

\section{Screening udang bebas WSSV}

Sebelum ditebar, dilakukan screening terhadap udang untuk memastikan udang tidak terinfeksi WSSV dan terkategori Specific Pathogen Free (WSSV negatif). Hasil uji PCR nya dapat dilihat dalam Gambar 2. Hasil pengujian terhadap sampel (S) menunjukkan tidak ada pita yang berpendar. Sehingga udang vaname yang akan digunakan dalam penelitian bebas WSSV (WSSV negatif).

\section{Ekspresi gen Lektin, Toll setelah infeksi}

Ekspresi gen Lektin dan Toll dari udang yang diberi pakan dengan dua dosis alginat berbeda pada 12, 24, 36 dan 48 hour post infection (hpi) nilainya bervariasi. Sebelum infeksi WSSV, ekspresi gen Toll pada udang yang diberi pakan sodium alginat dengan tiga dosis berbeda menunjukkan aktivitas up-regulated. Pada 24, 36 dan $48 \mathrm{hpi}$, ekspresi dari udang yang diberi pakan dengan dua dosis alginat yang berbeda nilainya menjadi down-regulated. (Gambar 3).

Ekspresi gen Lektin pada semua perlakuan memperlihatkan bahwa gen tersebut ter up-regulated, baik sebelum maupun sesudah infeksi WSSV, kecuali pada 12 hpi, udang yang diberi pakan sodium alginat dengan dosis 2,0 dan $4,0 \mathrm{~g} \mathrm{~kg}^{-1}$, yang mengalami down-regulated (Gambar 4).

Sesaat setelah mikroba menembus halangan fisik, seperti kulit, insang atau mukus pada kelenjar pencernaan, maka akan dikenali oleh Toll dan sel immun akan merespon sehingga menjadi aktif (Kumagai et al., 2008). Jalur Toll terutama melibatkan pertahanan melawan jamur, bakteria gram-positif dan virus serta mengatur suatu set gen yang besar termasuk diantaranya gen-gen antimicrobial peptide dan komponen gen yang terlibat dalam pembentukan pigmen melanin dan cascade pembekuan. Antioksidan yang bersifat protektif ini akan meningkat pada level transkripsi (Wang et al., 2012) untuk menurunkan secara cepat ROS yang diinduksi oleh patogen. Proses ini diartikan sebagai sebuah postphagocytic antioxidant self-protection system.

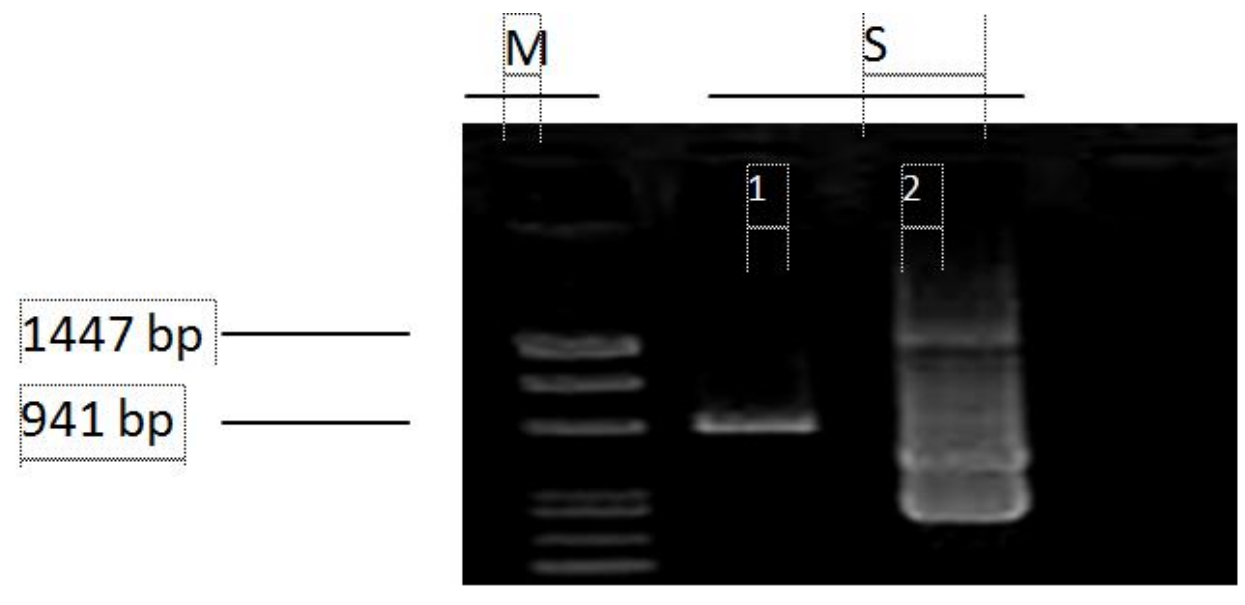

Gambar 1. Elektroforegram hasil nested PCR untuk konfirmasi infeksi WSSV. Lajur: M: 100 bp DNA ladder, P: kontrol positif (1447 bp dan 941 bp), N: kontrol negatif; 1: PCR tahap pertama, 2: PCR tahap kedua, S: sampel

Tabel 2. Perhitungan mortalitas udang pada jam ke 48 pada tiap konsentrasi untuk mendapatkan nilai $\mathrm{LD}_{50}$

\begin{tabular}{ccccccc}
\hline Log dosis $(\mathrm{x})$ & Udang uji $(\mathrm{n})$ & Mortalitas $(\mathrm{r})$ & $\mathrm{n}-\mathrm{r}$ & $\sum \mathrm{r}$ & $\sum(\mathrm{n}-\mathrm{r})$ & Total \\
\hline 2 & 30 & 18 & 12 & 18 & 12 & 30 \\
3 & 30 & 8 & 12 & 2 & 34 & 60 \\
4 & 30 & 4 & 26 & 30 & 50 & 80 \\
5 & 30 & 2 & 28 & 32 & 54 & 86 \\
\hline
\end{tabular}




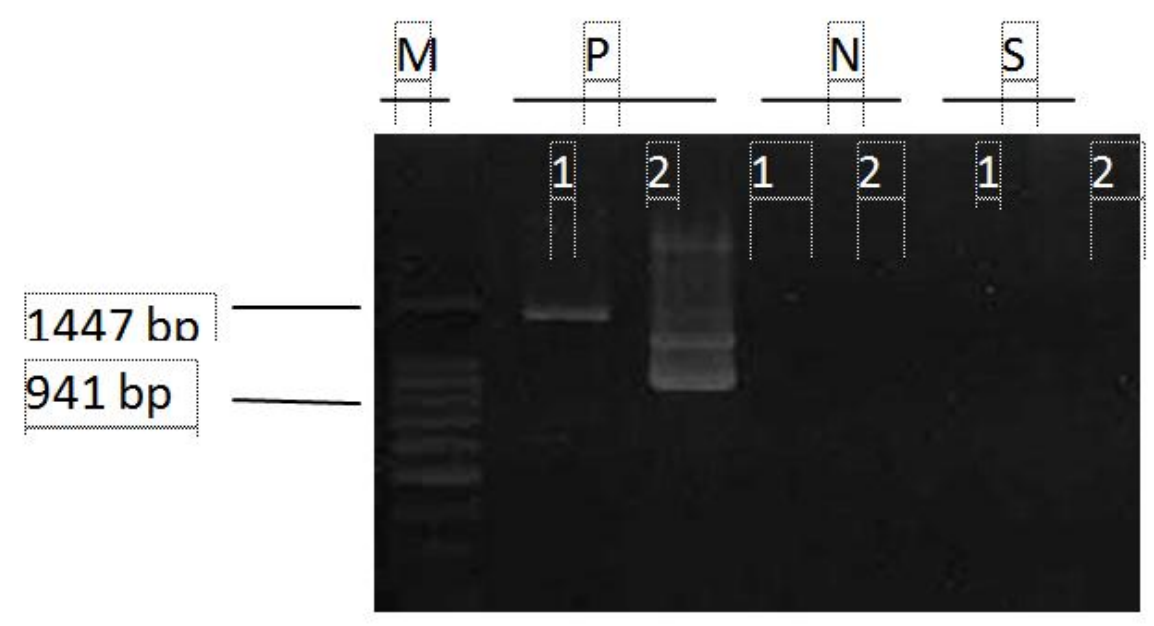

Gambar 2. Elektroforegram hasil nested PCR untuk konfirmasi infeksi WSSV. Lajur: M: 100 bp DNA ladder, P: kontrol positif (1447 bp dan 941 bp), N: kontrol negatif; 1: PCR tahap pertama, 2: PCR tahap kedua, S: sampel

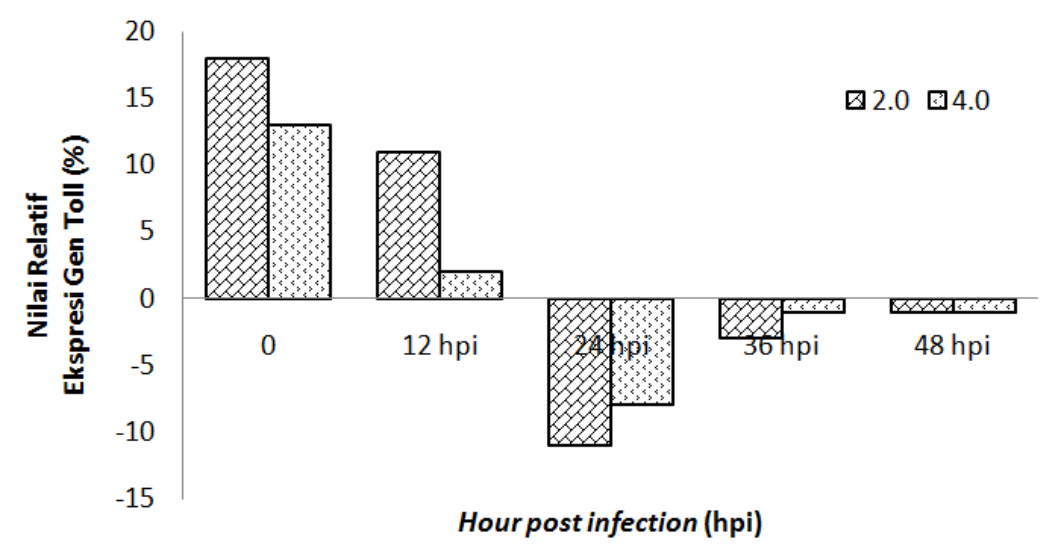

Gambar 3.Nilai ekspresi relatif gen Toll L. vannamei yang diberi pakan dengan suplementasi alginat pada dosis 0; 2,0 dan 4,0 $\mathrm{g} \mathrm{kg}^{-1}$ selama 0, 12, 24, 36 dan 48 hpi.

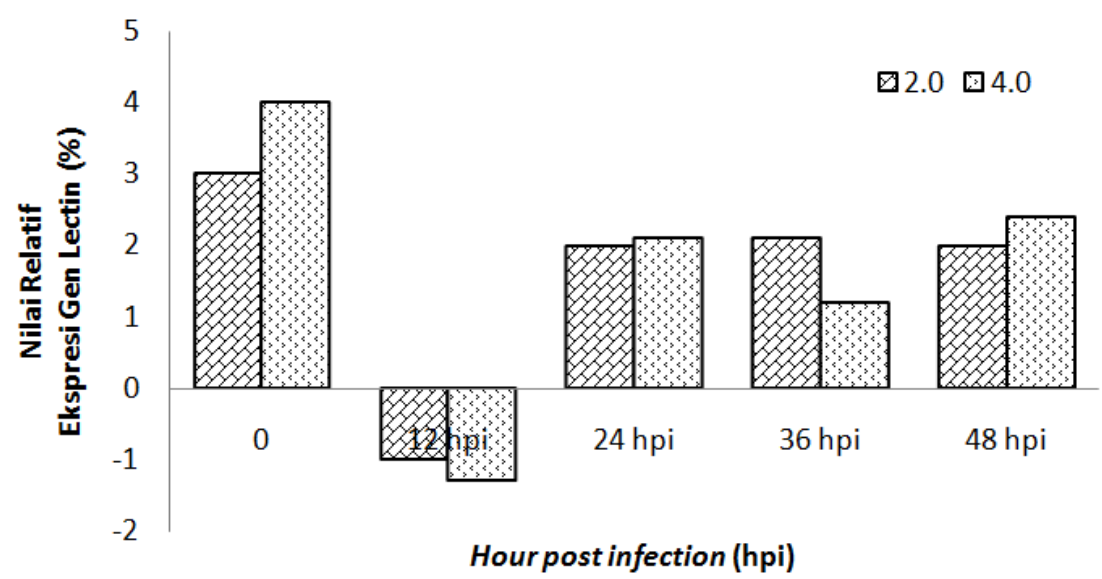

Gambar 4. Nilai ekspresi relatif gen Lektin L. vannamei yang diberi pakan dengan suplementasi alginat pada dosis $0 ; 2,0$ dan 4,0 $\mathrm{g} \mathrm{kg}^{-1}$ selama $0,12,24,36$ dan 48 hpi. 
Tabel 3. Jumlah copi WSSV dari udang L. vannamei yang diberi suplementasi pakan dengan sodium alginat dari Sargassum sp.

\begin{tabular}{cccc}
\hline Jumlah copi WSSV $\left(\mu \mathrm{g} \mathrm{g}^{-1}\right.$ dari total DNA $)$ & \multicolumn{3}{c}{ Alginat } \\
\cline { 2 - 4 } & Kontrol & $2,0 \mathrm{~g} \mathrm{~kg}^{-1}$ & $4,0 \mathrm{~g} \mathrm{~kg}^{-1}$ \\
\hline $0 \mathrm{hpi}$ & - & - & - \\
$12 \mathrm{hpi}$ & - & - & - \\
$24 \mathrm{hpi}$ & $19.10^{4}$ & - & $1,4.10^{4}$ \\
$36 \mathrm{hpi}$ & $612.10^{4}$ & 10,36 & $2,4.10^{4}$ \\
\hline
\end{tabular}

Keterangan : - = undetermine.

Berdasarkan pada hasil (Gambar 3), terindikasi bahwa ekspresi gen Toll pada udang yang diberi suplementasi pakan dengan sodium alginat pada dosis 2,0 dan 4,0 $\mathrm{g} \mathrm{kg}^{-1}$ dapat megalami down-regulated. Hal ini kemungkinan karena polisakarida pada alginat akan berikatan pada Toll udang vaname yang selanjutnya akan mengatur sistem enzim antioksidan dan meminimalkan ROS sehingga menyediakan immun homeostatis. Pada saat yang sama, dengan mempertimbangkan interaksi antara virus dan inang, maka dapat ditarik postulat bahwa polisakarida pada alginat yang berikatan dengan Toll akan mengganggu mekanisme jalur TLR-NF$\mathrm{\kappa B}$ sehingga akan menghambat replikasi virus didalam sel inang.

Lectin tipe-C adalah sebuah mannose binding lectin (MBL) yang dihasilkan dari hemosit granular. Lectin tipe-C mempunyai fungsi yang sangat penting dalam pengenalan patogen, sistem immun bawaan dan interaksi antar sel. Semua perilaku pengenalan-karbohidrat dari Lectin tipe-C yang ditampilkan oleh $L$. vannamei sangat menguntungkan apabila dilihat dari struktur dan fungsinya, yaitu domain pengenalankarbohidrat (CRD), yang merupakan domain yang sangat kompak karena terdiri dari 150 residu asam amino yang terdistribusi secara bervariasi pada beberapa organ spesifik.

Penelitian ini menunjukkan bahwa pengikatan polisakarida dari alginat oleh reseptor Lectin mampu melindungi udang dari infeksi oleh virus dan secara bertahap akan memperpanjang laju sintasan udang dalam menghadapi infeksi virus. Secara konsisten, ekspresi dari LectinmRNA mengalami up-regulated setelah 12 hpi (Gambar 4). Aktivitas ini berhubungan dengan fakta bahwa struktur alginat yang mengandung karbohidrat akan memungkinkan alginat untuk mengikat Lectin di hemosit. Lectin akan mengikat dengan afinitas yang tinggi pada manosa dan residu karbohidrat dengan jarak yang tepat. Sampel ekspresi gen pada penelitian ini diambil dari hemolim udang. Hal ini semakin menguatkan argumen bahwa aktivitas ini terjadi di hemosit, yang kemudian akan mengaktivasi sinyal mediator di bagian hilir yaitu IMD, IKKs dari jalur NF-kB. NF-kB mengalami fosforilasi dan translokasi di dalam nukleus dan secara bertahap akan mengubah ekspresi dari gen immun.

Molekul-molekul respon immun bawaan berhubungan dengan tingkat transkripsi gen dan ekspresi protein modulator saat pengenalan patogen (Musthaq \& Kwang., 2012). Ekspresi gen Lectin kemungkinan diatur melalui jalur sinyal NF-кB. Penelitian ini menjadi menarik, karena pada 12 hpi, transkrip gen Lektin anjlok akibat invasi WSSV dan mengalami down-regulated. Secara umum, CTL dari invertebrata bekerja untuk meminimalkan serangan patogen dengan cara "mengeroyok" atau membunuh mikroorganisme, memicu melanisasi atau enkapsulasi hemosit, dan mempromosikan transduksi sinyal untuk membangkitkan respon immun humoral.

\section{Jumlah copi WSSV setelah infeksi}

Jumlah copi $W S S V \mu \mathrm{g}^{-1}$ dari total DNA mengalami peningkatan pada semua perlakuan seiring dengan berjalannya hpi. Hal ini menjadi menarik dengan memperhatikan fakta bahwa udang yang diberi suplementasi pakan sodium alginat dengan dosis $2,0 \mathrm{~g} \mathrm{~kg}^{-1}$ pada $24 \mathrm{hpi}$, tidak terdeterminasi, dan kemudian meningkat sedikit pada akhir pengamatan yaitu 36 hpi. Jumlah copi WSSV pada kontrol yang tidak disuplementasi dengan alginat menunjukkan virus tertinggi.

Jumlah copi WSSV yang terukur pada kontrol jumlahnya sangat besar apabila dibandingkan dengan perlakuan lainnya. Pengukuran terhadap jumlah copi WSSV belum pernah dilaporkan oleh peneliti lain sebelumnya. Penelitian ini membuktikan bahwa mekanisme pertahanan dan proteksi maksimal terhadap serangan WSSV terjadi pada udang yang diberi suplementasi pakan dengan alginat. 


\section{Laju Sintasan}

Pada jam ke 96 setelah injeksi, laju sintasan $(\mathrm{P}<0,05)$ udang yang diberi pakan dengan dosis 2,0 dan 4,0 alginat $\mathrm{g} \mathrm{kg}^{-1}$ lebih tinggi apabila dibandingkan dengan perlakuan kontrol (Gambar $5)$.

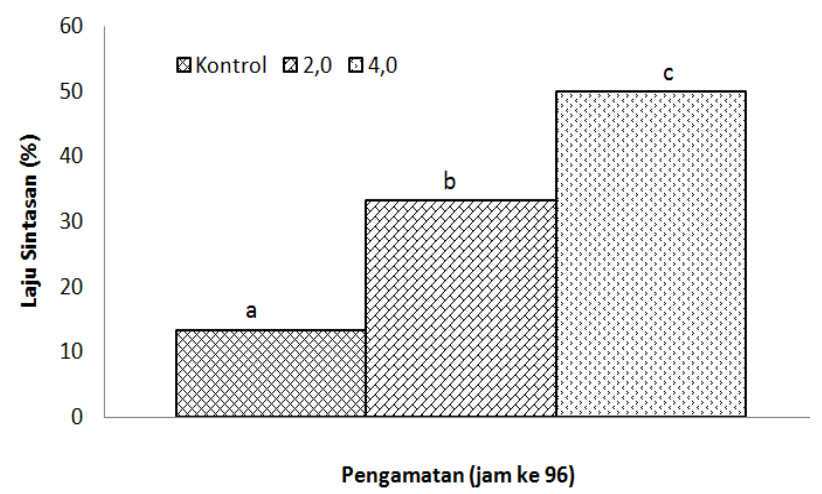

Gambar 5. Laju sintasan L. vannamei pada jam ke 96 yang diberi pakan dengan suplementasi aginat. Huruf yang berbeda pada data pada saat sampling menunjukkan adanya beda nyata $(\mathrm{p}<0,05)$.

Hasil yang serupa dipublikasikan oleh Sirirustananun et al, (2011) dan Lin et al, (2012) yang melaporkan adanya kenaikan tingkat proteksi terhadap serangan WSSV pada $L$. vannamei yang disuplementasi ekstrak Gracilaria tenuistipitata melalui proses perebusan. Ekstraksi Sargassum hemiphyllum (Huynh et al., 2011) yang dilakukan dengan metode perendaman juga mampu meningkatkan laju sintasan terhadap $L$. vannamei. Hal ini menunjukkan bahwa udang yang diberi suplementasi ekstrak rumput laut termasuk alginat mampu memberikan mekanisme pertahanan yang lebih baik dan proteksi yang lebih maksimal apabila dibandingkan dengan udang yang tidak tidak diberi suplementasi.

\section{KESIMPULAN}

Suplementasi alginat secara oral berpengaruh terhadap ekspresi gen Toll dan Lektin serta menghasilkan laju sintasan yang secara siginikan lebih tinggi dibandingkan kontrol (tanpa suplementasi).

\section{UCAPAN TERIMA KASIH}

Penelitian ini dapat terlaksana dengan bantuan sebagian dana dari Fakultas Pertanian UGM. Untuk itu penulis mengucapkan banyak terima kasih kepada Bapak Dr. Alim Isnansetyo atas dukungannya baik moril maupun materiil,
Sdri. Ayuningtyas, S.Pi.M. Biotech atas bantuannya dalam analisa dan drh. Ch. Retna Handayani atas dukungan dan fasilitasnya.

\section{DAFTAR PUSTAKA}

Bai, N., Zhang, W.B., Mai, K.S., Wang, X.J., Xu, W., \& Ma, H.M. 2010. Effects of discontinuous administration of $\beta$-glucan and glycyrrhizin on the growth and immunity of white shrimp Litopenaeus vannamei. Aquaculture. 306:218-224.

Cheng, W., Liu, C.H., Kuo, C.M. \& Chen, J.C. 2005. Dietary administration of sodium alginate Enhances the immune ability of white shrimp Litopenaeus vannamei and its resistance against Vibrio alginolyticus. Fish \& Shellfish Immunol. 18:1-12.

EPA 712-C-96-118, OPPTS 850-1075. 1996. Ecological Effects Test Guidelines, Fish Acute Toxicity Test, Freshwater and Marine, Office of Pesticide Programs, Office of Prevention, Pesticides, and Toxic Substances, U.S. Environmental Protection Agency. Washington DC. Revised April 1996.

Flegel, T.W., \& Sritunyalucksana, K. 2011. Shrimp Molecular Responses to Viral Pathogens. Mar. Biotechnol. 13:587-607. DOI : 10.1007/s10126-010-9287-x

Huynh, T.G., Yeh, S.T., Lin, Y.C., Shyu, J.F., Chen, L.L., \& Chen, J.C. 2011. White shrimp Litopenaeus vannamei immersed in seawater containing Sargassum hemiphyllu var. Chinense powder and its extract showed increased immunity and resistance against Vibrio alginolyticus and white spot syndrome virus. Fish \& Shellfish Immunol. 31:286-293.

Isnansetyo, A., Irpani, H.M., Wulansari, T.A., \& Kasanah, N. 2014. Oral Administration of Alginate from A Tropical Brown Seaweed, Sargassum sp. to Enhance Non-Spesific Defense In Walking Catfish (Clarias sp.) Aquacultura Indonesiana. 15:73-80

Jork, A., Thurmer, F., Cramer, H., Zimmermann, G., Gessne, P., Hamel, K., Hofmann, G., Kuttler, B., Hahn, H.J., Josimovic-Alasevic, O., \& Fritsch, K.G. 2000. Biocompatible alginate from freshly collected Laminaria pallida for implantation. Applied Microbiology and Biotechnology. 53:224-229

Kumagai, Y., Takeuchi, O. \& Akira. S. 2008. Pathogen recognition by innate receptors. $J$. Infection and Chemotheraphy. 14:86-92..

Lin, Y.C., Yeh, S.T., Li, C.C., Chen, L.L., Cheng, A.C. \& Chen, J.C. 2012. An immersion of Gracilaria tenuistipitata extract improves the 
immunity and survival of white shrimp Litopenaeus vannamei challenged with white spot syndrome virus. Fish \& Shellfish Immunology. 31:1239-1246

Liu, C.H., Yeh, S.P., Kuo, C.M., Cheng, W., \& Chou, C.H. 2006. The effect of sodium alginate on the immune response of tiger shrimp via dietary administration: Activity and gene transcription. Fish \& Shellfish Immunol. 21:442-452.

Livak, K.J., \& Schmittgen, T.D 2001. Analysis of Relative Gene Expression Data Using RealTime Quantitative PCR and the $2^{-\Delta \Delta \mathrm{CT}}$ Method. Methods. 25:402-408

Musthaq, S., \& Kwang, J. 2014. immunity in shrimp - A vaccination perspective against White spot syndrome virus. Developmental and Comparative Immunol. 46:279-290

Sirirustananun, N., J.C. Chen, Y.C. Lin, S.T. Yeh, C.H. Liou, L.L. Chen, S.S. Sim, \& S.L. Chiew. 2011. Dietary administration of a Gracilaria tenuistipitata extract enhances the immune response and resistance against Vibrio alginolyticus and white spot syndrome virus in the white shrimp Litopenaeus vannamei. Fish \& Shellfish Immunol. 31:848855.
Wang, X.W., \& J.X. Wang. 2012. Diversity and multiple functions of lectins in shrimp immunity. Developmental and Comparative Immunol. $36: 359-371$.

Yeh, S.T., C.S. Lee, \& J.C. Chen. 2006. Administration of hot-water extract of brown seaweed Sargassum duplicatum via immersion and injection enhances the immune resistance of white shrimp Litopenaeus vannamei. Fish \& Shellfish Immunol. 20:332-345.

Yu, Y-Y.,W-D, Chen., Y-J Liu., J. Niu., M. Chen, \& L-X. Tian. 2016. Effect of different dietary levels of Gracilaria lemaneiformis dry power on growth performance, hematological parameters and intestinal structure of juvenile Pacific white shrimp (Litopenaeus vannamei). Aquaculture. 450:356-362.

Yudiati, E., Isnansetyo, A., Murwantoko, Ayuningtyas, Triyanto, \& Handayani, C.R. 2016. Innate Immune Stimulating and genes up-regulating activities of three types of alginate from Sargassum siliquosum inPacific white shrimp, Litopenaeus vannamei. Fish \& Shellfish Immunol. 54:4653. 